Journal of Advanced Research in Fluid Mechanics and Thermal Sciences

\title{
Sayong Ball Clay Membrane for Copper and Nickel Removal from Effluent
}

\author{
Nurhanna Mohd Zaidan ${ }^{1}$, Norhayati Ahmad ${ }^{1,},{ }^{*}$ Yuzo Nakamura², Muazu Abubakar ${ }^{3}$ \\ Universiti Teknologi Malaysia (UTM), 81310, Skudai, Johor, Malaysia \\ Kagoshima University, 1-21-40 Korimoto, Kagoshima-shi, Japan \\ Department of mechanical Engineering, Bayero University Kano, Nigeria
}

\section{ARTICLE INFO}

\section{Article history:}

Received 1 November 2020

Received in revised form 18 December 2020

Accepted 18 December 2020

Available online 19 January 2021

\section{Keywords:}

Copper; nickel; removal; heavy metal; clay; adsorption agent; adsorption; gel casting; spark plasma sintering;

microfiltration; pore size

\section{ABSTRACT}

An adsorption filtration mechanism using porous ceramic membranes was proposed for the removal of heavy metals from the effluent of the UTM Lake. The effectiveness of the removal depends on kaolinite microparticle which is used as an adsorption agent in ceramic membranes. In this work, Sayong ball clay (SBC) from Malaysia was used in the preparation of the ceramic membrane. Sayong ball clay membranes were fabricated by gel casting (GC) and spark plasma sintering (SPS) methods. The effect of kaolinite and pore size on copper and nickel removal was investigated. X-ray fluorescence (XRF), X-ray diffraction (XRD), mercury porosimetry, and adsorption analysis were used to relate with the adsorption performance. It is found that kaolinite with the 14:1 ratio of monomers in the GC-SBC membrane performed the highest heavy metal removal.

\section{Introduction}

Rapid economic growth and industrial development contribute to continuous heavy metal contamination in the environment. This pollution is common in industries such as electroplating tannery and, mining. There are numerous ways of removing heavy metal through adsorption, reverse osmosis, precipitation, and electrodialysis processes [1,2]. Recently, heavy metals removal in wastewater using membrane-based ceramic has gained tremendous importance as suitable water and wastewater remediation. However, harsh chemicals during the processes tend to change the physical and chemical properties of the inorganic membrane leading to secondary effluent pollution subsequently may suffer higher costs for maintenance or repair. Adsorption and membrane filtration are widely investigated for heavy metal removal due to its advantages such as

\footnotetext{
* Corresponding author.

E-mail address: nhayatiahmad@utm.my
}

https://doi.org/10.37934/arfmts.79.2.131138 
withstand continuous and longer operation period, easy to set up and changed, high performance, low cost, and wider feed conditions [3-6]. Adsorption agents are known in the previous researches for the efficient removal of nickel and copper from effluent [7]. The adsorption mechanism only works in the existence of the adsorption agents on the surface where the heavy metal will accumulate. Previous researches [8-10] reported natural clay-based adsorption agents such as wood and moss are safe to aids the removal of heavy metals from effluents. The use of alternative low-cost and abundant clay for heavy metal removal has been emphasized recently [11,12]. Though there are lots of works on the use of clay as a ceramic membrane for the treatment of wastewater, however, there are few studies on the use of ball clay from Malaysia as a ceramic membrane for the removal of nickel and copper from wastewater. Among common adsorption agents used for the removal of nickel and copper ions is kaolinite from the Phyllosilicates class. A clay-based adsorption agent was used to remove heavy metals from effluent due to its inertness and environmentally friendly. Furthermore, it is also relatively cheaper compared to others such as zeolites, and activated carbon [13-16]. Authors [17,18] revealed that the removal of heavy metals from effluent by using kaolinite is through exchangeable ions. This agent consists of a combined 3D tetrahedral network of $\mathrm{SiO}_{4}$ and $\mathrm{AlO}_{4}$. The replacement of Si4+ by Al3+ ions creates a negative charge in the tetrahedron lattice which later will be occupied by nickel and copper ions. On the other hand, membrane technology is considered the most efficient technology for the removal of heavy metals from effluent in combination with the adsorption mechanism. One type of membrane filtration is microfiltration. This type of filtration offers many benefits such as automatic and continuous systems [19], an easy and cheaper process, mild operating conditions [20], and not easily fouling [21]. The pore size of microfiltration has a significant influence on the percentage of heavy metal ions that succeeds to be attracted to a membrane wall or pass through the open pore [22]. Larger pore size will decrease the probability of ions to be attracted onto the membrane wall, therefore easier the ions to pass through. The objective of this study was to use of porous ceramic microfiltration membrane in combination with kaolinite as an adsorption agent for the formation of adsorption assisted filtration process able to operate at cost-efficient while producing significantly filtered effluent with pore sizes and adsorption agent dependable. A low-cost clay, Sayong ball clay from Malaysia will be used due to their chemical and thermally inert ceramic as the membrane may stand very broad indifference conditions without showing structural changes that can affect their operational behavior. The heavy metal adsorption performances were related to XRD, XRF, Mercury Porosimetry, and adsorption analysis.

\section{Materials and Methods}

Both spark plasma sintering (SPS) and gel casting (GC) membranes were fabricated by using Sayong ball clay powder from Perak, Malaysia. Details of fabrication information over the GC and SPS membranes were found in $[23,24]$ but the different ratio of monomers (ROM) (Methacrylamide and N,N'Methylenebisacrylamide) and sintering temperatures were varied between $6: 1$ to $14: 1$ and $650^{\circ} \mathrm{C}$ to $1050^{\circ} \mathrm{C}$, respectively. Chemical composition and phases of the membranes before and after filtration were analyzed using X-ray fluorescence spectroscopy Rigaku 3065 (XRF) and X-Ray Diffraction-XL30 (XRD), respectively. The pore size of the membranes was measured using mercury intrusion porosimetry (Micromeritics AutoPore-iii). The membranes are disc geometry with a diameter of $\pm 30 \mathrm{~mm}$ and a thickness of $\pm 5 \mathrm{~mm}$ were fabricated by using the direct forming method. The membrane filtration unit setup is shown in Figure 1. The unit was installed with a back-flushing system. The filtration tests were conducted by using lake contaminated effluent, and the effluents were measured before and after filtration in terms of $\mathrm{pH}$, copper, and nickel contents. The 
spectrophotometer, DR1900 instrument was used to measure nickel and copper contents in the effluent based on ASTM D1886 and ASTM D1688, respectively.

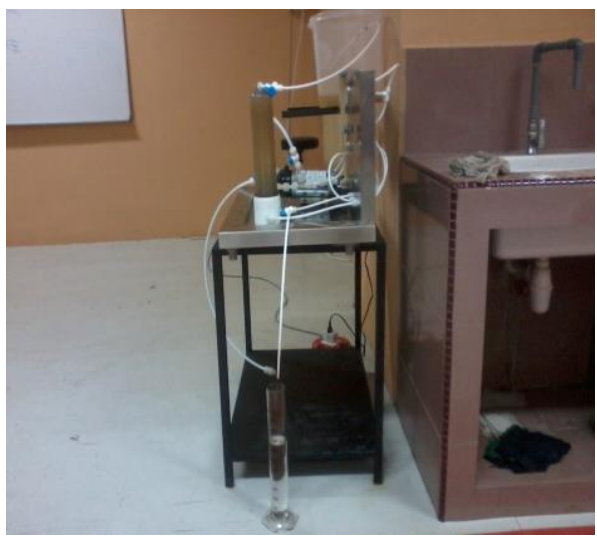

(a)

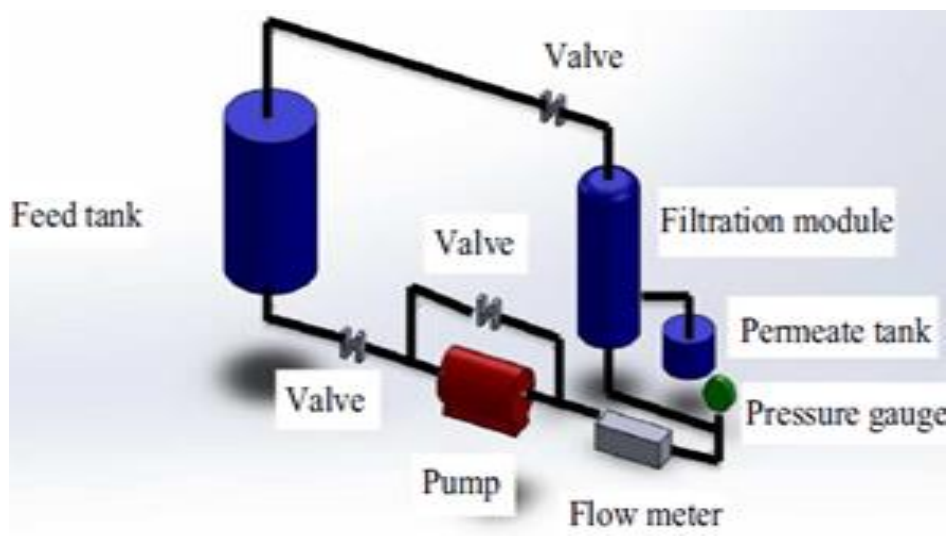

(b)

Fig. 1. Membrane filtration setup (a) filtration process and (b) its schematic diagram [25]

\section{Results and Discussions}

Table 1 showed the chemical compositions of Sayong ball clay. It is observed that raw SBC shows a 93\% amount of future-to-be kaolinite (combination between silica and alumina). Figure 2 and 3 show the pores size distribution for SPS and GC membranes. The pores size distributions decreased as ROM $(6: 1$ to $14: 1)$ and sintering temperatures $\left(650^{\circ} \mathrm{C}\right.$ to $\left.1050^{\circ} \mathrm{C}\right)$ increases. Authors [26-28] stated, these parameters can be attributed to more consolidation of the membrane powders as the temperature and ROM varied. Thus, affect the pores size distributions. The 6 and 8 ROM membranes presented bimodal to multimodal pore size distribution as compared to 10-14 ROM. SPS membranes presented a narrow peak indicated pores size is homogeneous as shown in Figure 2. This can be explained by the broader channel for diffusion and more available active sites for interaction which could improve adsorption amount [29]. However, SPS membranes were involved with high temperatures during sample preparation, leading to loss of adsorption agent due to the collapse of kaolinite structures that changed to other phases based on Eq. (1)-(3) [30].

Table 1

Chemical compositions by using XRF

\begin{tabular}{ll}
\hline & Compositions (mass \%) \\
\hline $\mathrm{SiO}_{2}$ & 73.4 \\
$\mathrm{Al}_{2} \mathrm{O}_{3}$ & 19.6 \\
$\mathrm{Na}_{2} \mathrm{O}$ & 2.4 \\
$\mathrm{~K} 2$ & 1.2 \\
$\mathrm{CaO}$ & 1.1 \\
$\mathrm{MgO}$ & 1.1 \\
others & 1.2 \\
\hline
\end{tabular}




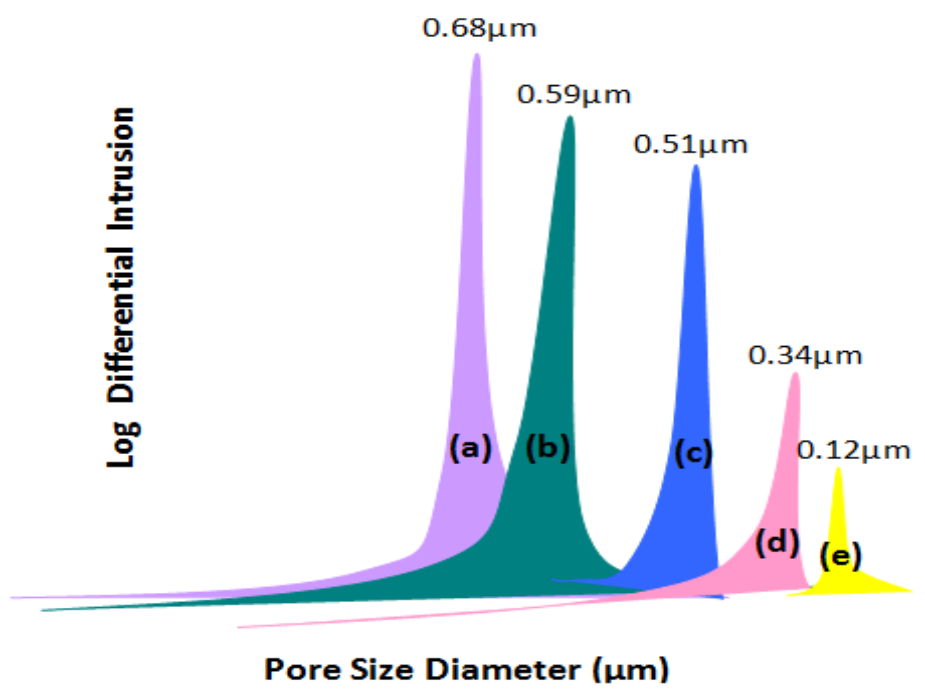

Fig. 2. Pore size distribution of the membranes fabricated using SPS sintered at (a) $650 \circ \mathrm{C}$, (b) $725^{\circ} \mathrm{C}$, (c) $800 \circ \mathrm{C}$, (d) $900 \circ \mathrm{C}$, and (e) $1050 \circ \mathrm{C}$, respectively

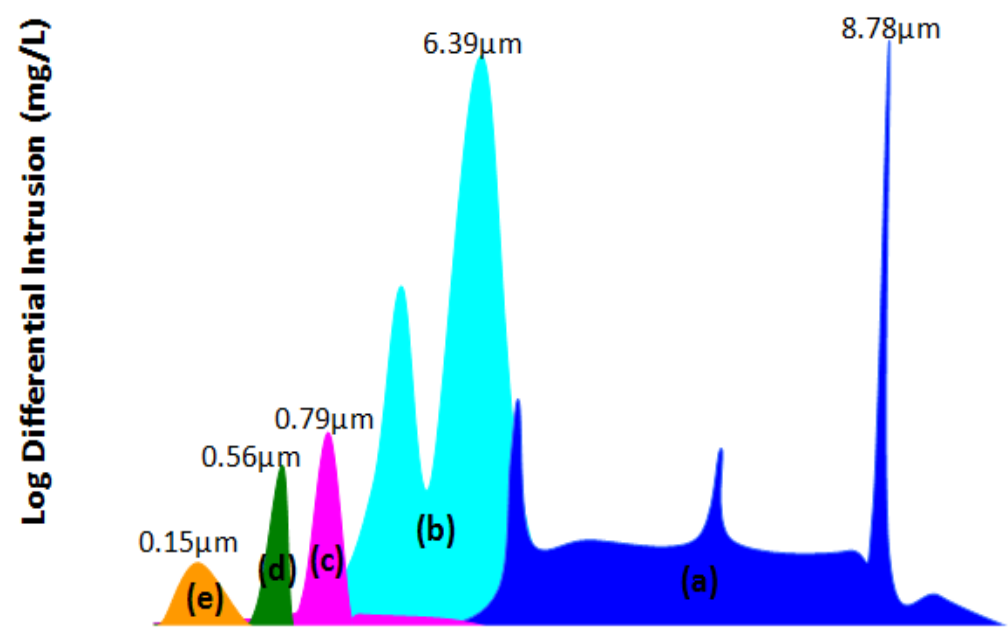

Pore Size Diameter (um)

Fig. 3. Pore size distribution of the membranes fabricated using gel casting for ratio of monomers (a) 6 , (b) 8, (c) 10 , (d) 12 , and (e) 14 , respectively

$\mathrm{Al}_{2} \mathrm{O}_{3} \cdot 2 \mathrm{SiO}_{2} \cdot 2 \mathrm{H}_{2} \mathrm{O}($ Kaolinite $) \rightarrow \mathrm{Al}_{2} \mathrm{O}_{3} \cdot 2 \mathrm{SiO}_{2}($ Metakaolin $)+2 \mathrm{H}_{2} \mathrm{O}$

$\mathrm{Al}_{2} \mathrm{O}_{3} \cdot 2 \mathrm{SiO}_{2}($ Metakaolin $) \rightarrow \mathrm{Al}_{2} \mathrm{O}_{3} \cdot 3 \mathrm{SiO}_{2}($ spinal $)+\mathrm{SiO}_{2}($ Quartz $)$

$\mathrm{Al}_{2} \mathrm{O}_{3} \cdot 3 \mathrm{SiO}_{2}($ spinal $) \rightarrow \mathrm{SiO}_{2}($ Tridymite $)+\mathrm{Al}_{2} \mathrm{O}_{3} \cdot 2 \mathrm{SiO}_{2}($ Mullite $)+\mathrm{Al}_{2} \mathrm{O}_{3}($ Corundum $)$

From Table 2, nickel and copper removal percentage showed increment as ROM increased and sintering temperature decreased. These results coincided with the XRD pattern depicted in Figure 4 indicated the decrement of kaolinite for SPS membranes with temperature increasing as based on the intensity of the kaolinite. The results showed that the amount of the adsorption agent significantly affects the success of heavy metal removal in effluent other than the pore size factor. This statement valid with XRD pattern for the membrane fabricated by SPS sintered at $900^{\circ} \mathrm{C}$ with 
fairly least removal percentage as copper and nickel elements has found in the membrane after been filtered as shown in Figure 5. For GC membranes, changing in ROM does not affect the phase transformation as no heating is involved. Increasing ROM will yield a smaller pore size up to 0.15 $\mu \mathrm{m}$ and more homogeneous pore size distribution as graphs changed from multimodal to unimodal distributions. A large amount of adsorption agent and smaller pore size contributes much in successful of heavy metal removal based on the adsorption analysis of the membrane fabricated using gel casting with ROM 14. Even though the maximum temperature for both methods was set at a constant value which is $1050 \stackrel{\circ}{ } \mathrm{C}$, the mechanism in the spark plasma sintering leads to better particle contact and densification, which affects the transformation of phases in the membrane. The contrast data between nickel and copper adsorption analysis is because of optimum $\mathrm{pH}$ factor where current 7.0-7.5 $\mathrm{pH}$ of effluent (Table 3) is optimum $\mathrm{pH}$ for copper adsorption compared to nickel that required 9-10 $\mathrm{pH}$ to adsorb the heavy metal efficiently [31].

\section{Table 2}

Pore sizes and adsorption analyses using mercury intrusion porosimetry and spectrophotometer, respectively

\begin{tabular}{llll} 
& \multicolumn{2}{l}{ Adsorption $(\%)$} & Mean pore sizes $(\mu \mathrm{m})$ \\
\cline { 2 - 3 } & Copper & Nickel & \\
\hline GC-6 & 68 & 12 & 8.78 \\
GC-8 & 75 & 23 & 6.39 \\
GC-10 & 81 & 44 & 0.79 \\
GC-12 & 84 & 50 & 0.56 \\
GC-14 & 87 & 59 & 0.15 \\
SPS-650 & 83 & 18 & 0.68 \\
SPS-700 & 80 & 18 & 0.53 \\
SPS-725 & 76 & 18 & 0.59 \\
SPS-875 & 65 & 17 & 0.18 \\
SPS-900 & 62 & 17 & 0.12 \\
\hline
\end{tabular}

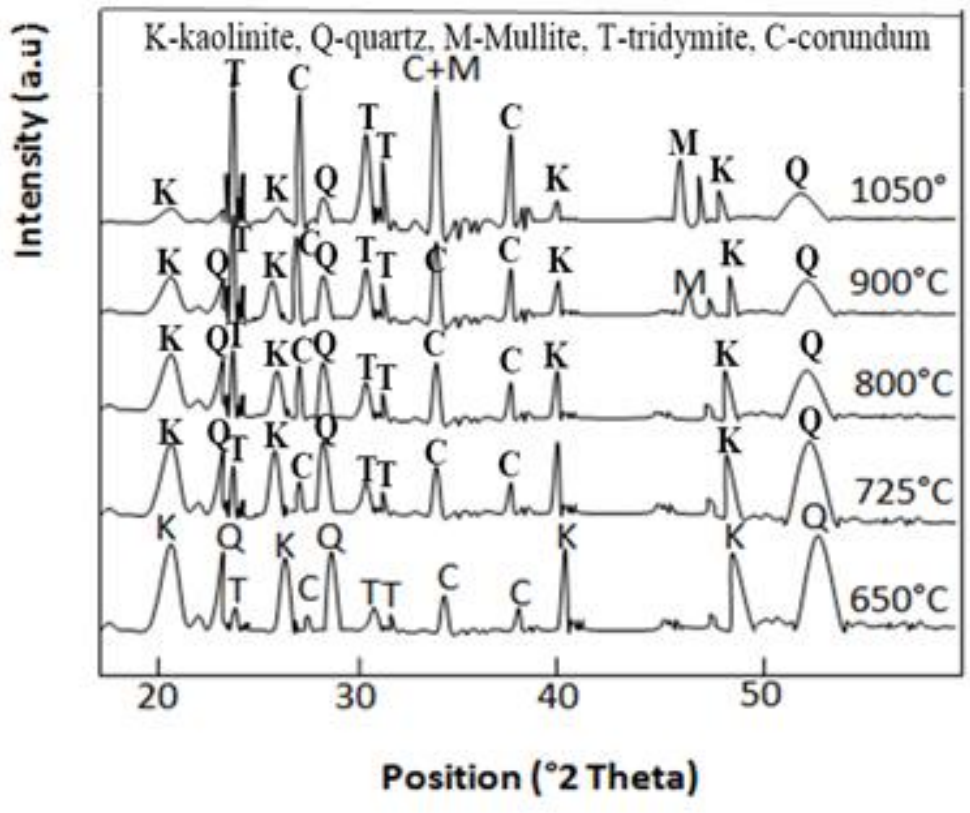

Fig. 4. XRD patterns of sintered membrane fabricated from SPS with various sintering temperatures 
K-kaolinite, Q-quartz, M-mullite, T-tridymite, C-corundum,

Cu-Copper, Ni-Nickel
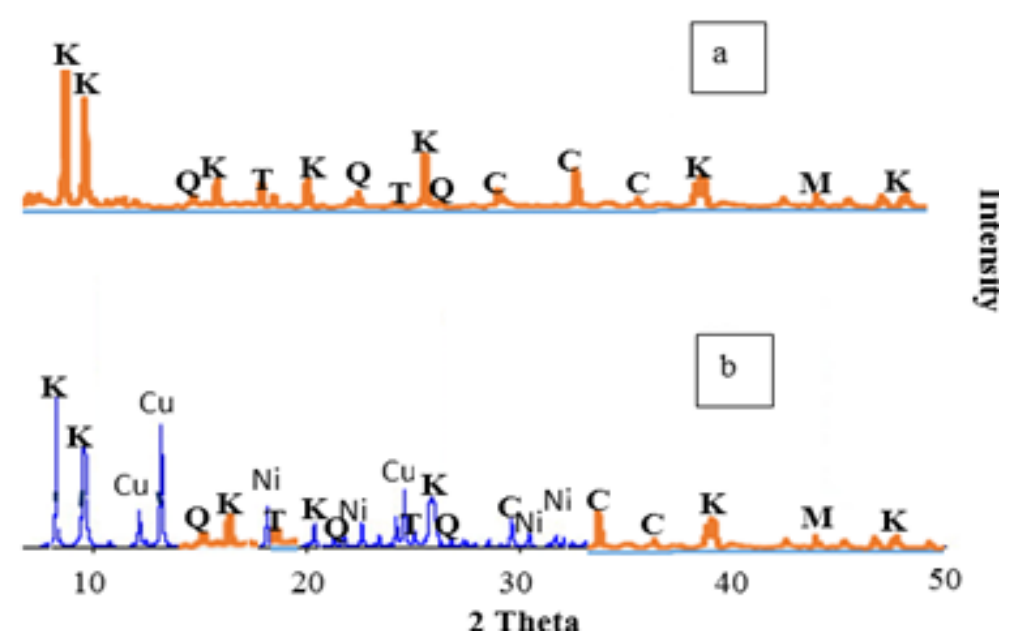

Fig. 5. XRD patterns for Nickel and Copper content in (a) virgin (before filtration) and (b) fouled (after filtration) SPS-900 ball clay membrane

Table 3

Characteristics of wastewater as taken from UTM lake

\begin{tabular}{ll}
\hline Parameters & Values \\
\hline Copper(mg/L) & 0.11 \\
Nickel(mg/L) & 0.08 \\
$\mathrm{pH}$ & $7.00-7.50$ \\
\hline
\end{tabular}

\section{Conclusions}

Clay-based kaolinite is suitable to be used as a material for heavy metal removal. This study has shown the effect of kaolinite as an adsorption agent and pore sizes on heavy metal removal by varying ratios of monomers and sintering temperatures using gel casting and spark plasma sintering method, respectively. The membrane fabricated by gel casting with the ratio of monomers 14:1 that possessed optimum pores $(0.15 \mu \mathrm{m})$ and the highest amount of kaolinite as the adsorption agent contributes to maximum removal of nickel and copper ions $59 \%$ and $87 \%$, respectively. It was also found that effluent $\mathrm{pH}$ plays a significant role in the efficiency of the adsorption agent to adsorb both heavy metals.

\section{Acknowledgement}

The authors would like to express their thanks to the Research Management Centre (RMC) of Universiti Teknologi Malaysia (UTM) for the Grants (4B537, 00L65, 06G32), Faculty of Mechanical Engineering, UTM and Ministry of Education of Malaysia (FRGS 5F421) for their support.

\section{References}

[1] Jeon, Choong, Jae Yeon Park, and Young Je Yoo. "Removal of heavy metals in plating wastewater using carboxylated alginic acid." Korean Journal of Chemical Engineering 18, no. 6 (2001): 955-960. https://doi.org/10.1007/BF02705625

[2] Erdem, Emin, N. Karapinar, and R. Donat. "The removal of heavy metal cations by natural zeolites." Journal of colloid and interface science 280, no. 2 (2004): 309-314.

https://doi.org/10.1016/i.jcis.2004.08.028 
[3] Neale, C. Nelson, R. Y. Bricka, and Allen C. Chao. "Evaluating acids and chelating agents for removing heavy metals from contaminated soils." Environmental Progress 16, no. 4 (1997): 274-280.

https://doi.org/10.1002/ep.3300160416

[4] Khodadoust, Amid P., Krishna R. Reddy, and Kranti Maturi. "Effect of different extraction agents on metal and organic contaminant removal from a field soil." Journal of Hazardous Materials 117, no. 1 (2005): 15-24. https://doi.org/10.1016/i.jhazmat.2004.05.021

[5] Shin, Mari, Suzelle F. Barrington, William D. Marshall, and Jin-Woo Kim. "Effect of surfactant alkyl chain length on soil cadmium desorption using surfactant/ligand systems." Chemosphere 58, no. 6 (2005): 735-742.

https://doi.org/10.1016/i.chemosphere.2004.06.004

[6] Zhang, Weihua, Daniel CW Tsang, and Irene MC Lo. "Removal of Pb and MDF from contaminated soils by EDTAand SDS-enhanced washing." Chemosphere 66, no. 11 (2007): 2025-2034.

https://doi.org/10.1016/i.chemosphere.2006.10.017

[7] Runtti, Hanna, Sari Tuomikoski, Teija Kangas, Ulla Lassi, Toivo Kuokkanen, and Jaakko Rämö. "Chemically activated carbon residue from biomass gasification as a sorbent for iron (II), copper (II) and nickel (II) ions." Journal of water process engineering 4 (2014): 12-24.

https://doi.org/10.1016/i.jwpe.2014.08.009

[8] Di Palma, Anna, Aridane G. González, Paola Adamo, Simonetta Giordano, Ralf Reski, and Oleg S. Pokrovsky. "Biosurface properties and lead adsorption in a clone of Sphagnum palustre (Mosses): Towards a unified protocol of biomonitoring of airborne heavy metal pollution." Chemosphere 236 (2019): 124375. https://doi.org/10.1016/j.chemosphere.2019.124375

[9] Ares, A., J. Aboal, A. Carballeira, and J. A. Fernández. "Do moss bags containing devitalized Sphagnum denticulatum reflect heavy metal concentrations in bulk deposition?." Ecological indicators 50 (2015): 90-98. https://doi.org/10.1016/i.ecolind.2014.10.030

[10] Liu, Ling, Xiaoping Guo, Shuqi Wang, Lei Li, Yang Zeng, and Guanhong Liu. "Effects of wood vinegar on properties and mechanism of heavy metal competitive adsorption on secondary fermentation based composts." Ecotoxicology and Environmental Safety 150 (2018): 270-279.

https://doi.org/10.1016/i.ecoenv.2017.12.037

[11] Gupta, Vinod K., P. J. M. Carrott, M. M. L. Ribeiro Carrott, and Suhas. "Low-cost adsorbents: growing approach to wastewater treatment-a review." Critical reviews in environmental science and technology 39, no. 10 (2009): 783-842. https://doi.org/10.1080/10643380801977610

[12] Koteja, Anna, and Jakub Matusik. "Di-and triethanolamine grafted kaolinites of different structural order as adsorbents of heavy metals." Journal of Colloid and Interface Science 455 (2015): 83-92. https://doi.org/10.1016/i.jcis.2015.05.027

[13] Kentish, S. E., and G. W. Stevens. "Innovations in separations technology for the recycling and re-use of liquid waste streams." Chemical Engineering Journal 84, no. 2 (2001): 149-159.

https://doi.org/10.1016/S1385-8947(01)00199-1

[14] Chatterjee, S., R. K. Asthana, A. K. Tripathi, and S. P. Singh. "Metal removal by selected sorbents." Process biochemistry 31, no. 5 (1996): 457-462.

https://doi.org/10.1016/0032-9592(95)00091-7

[15] Tien, C-J. "Biosorption of metal ions by freshwater algae with different surface characteristics." Process Biochemistry 38, no. 4 (2002): 605-613. https://doi.org/10.1016/S0032-9592(02)00183-8

[16] Zouboulis, A. I., M. X. Loukidou, and K. A. Matis. "Biosorption of toxic metals from aqueous solutions by bacteria strains isolated from metal-polluted soils." Process biochemistry 39, no. 8 (2004): 909-916.

https://doi.org/10.1016/S0032-9592(03)00200-0

[17] Aşçı, Y., M. A. C. İ. D. Nurbaş, and Y. Sağ Açıkel. "Sorption of Cd (II) onto kaolin as a soil component and desorption of Cd (II) from kaolin using rhamnolipid biosurfactant." Journal of Hazardous Materials 139, no. 1 (2007): 50-56. https://doi.org/10.1016/i.jhazmat.2006.06.004

[18] Ibrahim, Hanan S., Tarek S. Jamil, and Eman Z. Hegazy. "Application of zeolite prepared from Egyptian kaolin for the removal of heavy metals: II. Isotherm models." Journal of Hazardous materials 182, no. 1-3 (2010): 842-847. https://doi.org/10.1016/i.jhazmat.2010.06.118

[19] Abadi, Sareh Rezaei Hosein, Mohammad Reza Sebzari, Mahmood Hemati, Fatemeh Rekabdar, and Toraj Mohammadi. "Ceramic membrane performance in microfiltration of oily wastewater." Desalination 265, no. 1-3 (2011): 222-228. https://doi.org/10.1016/i.desal.2010.07.055 
[20] Sheikhi, Mohammad, Mehran Arzani, Hamid Reza Mahdavi, and Toraj Mohammadi. "Kaolinitic clay-based ceramic microfiltration membrane for oily wastewater treatment: assessment of coagulant addition." Ceramics International 45, no. 14 (2019): 17826-17836.

https://doi.org/10.1016/i.ceramint.2019.05.354

[21] Garmsiri, Ehsan, Yaser Rasouli, Mohsen Abbasi, and Amir Abbas Izadpanah. "Chemical cleaning of mullite ceramic microfiltration membranes which are fouled during oily wastewater treatment." Journal of Water Process Engineering 19 (2017): 81-95.

https://doi.org/10.1016/i.jwpe.2017.07.012

[22] Coman, V., B. Robotin, and P. Ilea. "Nickel recovery/removal from industrial wastes: A review." Resources, Conservation and Recycling 73 (2013): 229-238.

https://doi.org/10.1016/i.resconrec.2013.01.019

[23] Ahmad, Norhayati, and Nurhanna Binti Mohd Zaidan. "Effect of sintering temperature on membrane properties of Sayong ball clay." In Applied Mechanics and Materials, vol. 315, pp. 349-353. Trans Tech Publications Ltd, 2013. https://doi.org/10.4028/www.scientific.net/AMM.315.349

[24] Ahmad, Norhayati, Nurhanna Binti Mohd Zaidan, and Maisarah Mohd Bazin. "Fabrication and Characterization of ceramic membrane by Gel Cast technique for water filtration." In Advanced Materials Research, vol. 686, pp. 280284. Trans Tech Publications Ltd, 2013. https://doi.org/10.4028/www.scientific.net/AMR.686.280

[25] Abubakar, Muazu, and Norhayati Ahmad. "Effect of milling time on the performance of ceramic membrane from ball clay for the treatment of nickel plating wastewater." Journal of the Australian Ceramic Society 55, no. 3 (2019): 667-679.

https://doi.org/10.1007/s41779-018-0276-2

[26] Olevsky, Eugene A., Sastry Kandukuri, and Ludo Froyen. "Consolidation enhancement in spark-plasma sintering: Impact of high heating rates." Journal of Applied Physics 102, no. 11 (2007): 114913.

https://doi.org/10.1063/1.2822189

[27] Cavaliere, Pasquale, ed. Spark plasma sintering of materials: advances in processing and applications. Springer, 2019. https://doi.org/10.1007/978-3-030-05327-7

[28] Dudek, Magdalena, Bartłomiej Lis, Elwira Kocyło, Alicja Rapacz-Kmita, Michał Mosiałek, Marcin Gajek, Radosław Lach et al. "Utilisation of methylcellulose as a shaping agent in the fabrication of Ba $0.95 \mathrm{Ca} 0.05 \mathrm{Ce} 0.9$ Y 0.103 proton-conducting ceramic membranes via the gelcasting method." Journal of Thermal Analysis and Calorimetry 138, no. 3 (2019): 2077-2090.

https://doi.org/10.1007/s10973-019-08856-8

[29] Maged, Ali, Ismael Sayed Ismael, Sherif Kharbish, Binoy Sarkar, Sirpa Peräniemi, and Amit Bhatnagar. "Enhanced interlayer trapping of $\mathrm{Pb}$ (II) ions within kaolinite layers: intercalation, characterization, and sorption studies." Environmental Science and Pollution Research 27, no. 2 (2020): 1870-1887. https://doi.org/10.1007/s11356-019-06845-w

[30] Glass, Herbert D. "High-temperature phases from kaolinite and halloysite." American Mineralogist: Journal of Earth and Planetary Materials 39, no. 3-4 (1954): 193-207.

[31] Barakat, M. A. "New trends in removing heavy metals from industrial wastewater." Arabian journal of chemistry 4, no. 4 (2011): 361-377.

https://doi.org/10.1016/i.arabjc.2010.07.019 